\title{
Prevalence of Oral Lesions in the Elderly
}

\author{
I Minic 1 , A Pejcic 1 , M Kostic 2 , N Krunic 2 , D Mirkovic 3 , M Igic ${ }^{2}$
}

\begin{abstract}
Objective: Geriatric dentistry refers to dealing with oral diseases including prevention and treatment in old individuals. The aim of this investigation was to examine the types and frequency of oral lesions in the elderly.

Subjects and Methods: The study involved 75 elderly persons. The clinical diagnosis was established by correlating the aetiological factor associated with the lesion and by systematic examination of the oral mucosa and classifying those alterations according to the epidemiological guidelines for the diagnosis of oral mucosal diseases. During the clinical examination, the following elements were analysed: features of the lesion, anatomical location, extension, aetiological factors or related factors, dental status, alcohol, tobacco, trauma, use of prosthesis and if such were well adapted.

Results: Sixty lesions were diagnosed in 75 patients. These were classified according to clinical, histopathological and microbiological diagnosis and were distributed into 15 different clinical entities. The more prevalent pathologies were inflammatory, reactive and associated with long-term use of prostheses or ill-adapted prostheses, since 67\% of the patients with lesions were using prostheses. Of the lesions related to prosthesis use, denture stomatitis was the most common one, representing 20 cases $(33.3 \%)$. The second most frequent lesion was erythematous candidiasis $(10 \%)$. The other most frequent lesions in this study were lingua plicata, xerostomia and pseudomembranous candidiasis.

Conclusion: Oral and perioral tissues undergo different functional and structural changes with ageing. The role of the dentist and stomatologist includes the management of systemic, nutritional and pharmacological oral manifestations in order to establish an early diagnosis and subsequent accurate treatment.
\end{abstract}

Keywords: Elderly, oral lesions, prevalence

\section{Prevalencia de las lesiones orales en los ancianos}

\author{
I Minic ${ }^{1}$, A Pejcic ${ }^{1}$, M Kostic ${ }^{2}$, N Krunic ${ }^{2}$, D Mirkovic ${ }^{3}$, M Igic ${ }^{2}$
}

\begin{abstract}
RESUMEN
Objetivos: La odontología geriátrica se refiere a la atención a las enfermedades orales, incluyendo la prevención y el tratamiento en los ancianos. El objetivo de esta investigación fue examinar los tipos y frecuencia de las lesiones orales en los ancianos.

Sujetos y métodos: En el estudio participaron 75 personas mayores. El diagnóstico clínico se estableció mediante la correlación del factor etiológico asociado y la lesión, así como mediante el examen sistemático de la mucosa oral, y la clasificación de esas alteraciones según las pautas epidemiológicas para el diagnóstico de enfermedades de la mucosa oral. Durante el examen clínico, se analizaron los siguientes elementos: características de la lesión, localización anatómica, extensión, factores etiológicos o factores relacionados, estado dental, alcohol, tabaco, trauma, uso y correcta adaptación de las prótesis.

Resultados: Sesenta las lesiones fueron diagnosticadas en 75 pacientes. Estos fueron clasificados según el diagnóstico clínico, histopatológico y microbiológico y se distribuyeron en 15 diferentes entidades clínicas. Las patologías más prevalentes fueron las inflamatorias, las reactivas, y las aso-
\end{abstract}

From: ${ }^{1}$ Department of Periodontology and Oral Medicine, ${ }^{2}$ Department of Prosthodontics, Medical Faculty, University of Nis, Serbia and ${ }^{3}$ Private practice "Smile-dent", Nis, Serbia.
Correspondence: I Minic, Blvd Nikole Tesle 63/8, 18000 Nis, Serbia. Fax:+381643004883; e-mail: ivanminic@yahoo.com 
ciadas con el uso prolongado de prótesis o prótesis mal adaptadas, ya que el 67\% de los pacientes con las lesiones usaban prótesis. De las lesiones relacionadas con el uso de prótesis, la estomatitis protésica fue la más común, ocurriendo en 20 casos (33.3\%). La lesión más frecuente en segundo lugar fue la candidiasis eritematosa (10\%). Las otras lesiones más frecuentes en este estudio fueron la lengua frisurada o escrotal, la xerostomía, y la candidiasis pseudomembranosa.

Conclusión: Los tejidos orales y periorales sufren diversos cambios estructurales y funcionales con el envejecimiento. El papel del odontólogo y el estomatólogo incluye el tratamiento de las manifestaciones orales sistémicas, nutricionales y farmacológicas con el fin de establecer un diagnóstico precoz y el posterior tratamiento preciso.

Palabras claves: ancianos, lesiones orales, prevalencia

West Indian Med J 2016; 65 (2): 376

\section{INTRODUCTION}

Geriatric medicine deals with the social, psychological and clinical aspects of diseases in older individuals. Geriatric dentistry refers to dealing with oral diseases, including prevention and treatment, in old individuals (1). Ageing is the accumulation of changes over time. Ageing in humans is a multidimensional process that includes physical and psychosocial changes. The decline in oral health can result in limitation of oral cavity function due to oral disease, tissue damage and pain, leading to the avoidance of certain daily activities (2).

The elderly are at greater risk for developing oral disease since a longer lifespan results in more medically compromising conditions or systemic disease with oral manifestations (3). Therefore, most oral changes experienced by the elderly are not the result of the ageing process itself, but are the consequences of systemic diseases, pharmacotherapy, functional disabilities and cognitive impairment. Thus, the management of oral problems in elderly patients does not depend on the development of new technical skills, but rather on the knowledge of biological, psychological and social aspects of age-related changes and disease-related changes and the role of an interdisciplinary team $(4,5)$.

The oral health of the elderly is, in part, precarious, as the majority use or require some form of dental prostheses. The average number of teeth in the oral cavity is typically minimal and the incidence of root caries and periodontal disease is high. This trend often directly influences the quality of life of the elderly, causing psychological, physical and social distress to the patient. The most common causes of tooth loss are caries and periodontal disease. Often, edentulism occurs as a secondary result of systemic diseases that enhance periodontal disease, or as a result of iatrogenic effects, trauma, or damaging patient habits such as drugs, alcohol or tobacco use.

As well, patients who suffer from various congenital syndromes may exhibit an absence of some or all teeth. Elderly patients also tend to exhibit a low demand for professional dental care, and are often noncompliant for both preventative and restorative dental treatments. It has been found that there is an adaptation of sorts to edentulism by elderly patients as they age. Typically, as age increases, the impact of oral health on the overall quality of life decreases (6).
Research on the oral health status of elderly populations has been limited in frequency and scope. However, lingual varicosities, glossitis and atrophy of the taste buds and the salivary glands, with variable degrees of xerostomia, periodontal disease and increased risk of developing malignancies have all been reported with ageing (7). Furthermore, dental changes including abrasion, attrition and caries increase with ageing (8). In addition, there is a lack of good descriptive and longitudinal data on saliva and salivary gland function, tongue and oral sensation status, and lips and perioral tissue changes with ageing. Thus, the aim of this article is to review the oral changes including salivary gland and saliva, tongue and oral sensation, lips, perioral tissues, level of periodontal disease and oral infections with ageing.

\section{SUBJECTS AND METHODS}

The studied population comprised of institutionalized patients at the geriatric unit in Nis and those attending the outpatient facility at the dental service of the unit, during August to October 2013. The institutionalized population consisted of 80 patients; of these, 75 signed the written consent to participate in the investigation and agreed to be clinically evaluated by oral examination and to fulfil the inclusion criteria. All elderly patients who could not be present at the clinic that day or who did not allow the clinical oral examination were excluded. Finally, the study was conducted on 75 patients: 70 institutionalized and five non-institutionalized patients older than 60 years.

Each patient was evaluated using a designed chart and was clinically examined. The clinical diagnosis was established by correlating the aetiological factor associated with the lesion and by systematic examination of the oral mucosa and classifying those alterations according to the epidemiological guidelines for the diagnosis of oral mucosal diseases [World Health Organization] (9). In addition, in those cases requiring further examination, biopsies or cytology were performed to establish an accurate definite diagnosis. The elements to evaluate during the questionnaire included: general status of the patient, systemic diseases, medications used, age, gender, alcohol and tobacco consumption, habits (trauma) and prosthetic or other appliances use. During the clinical examination, 
the following elements were analysed: features of the lesion, anatomical location, extension, aetiological factors or related factors, dental status, alcohol, tobacco, trauma, use of prosthesis and if these were well adapted. The study was approved by the Ethics Committee of the Medical Faculty, University of Nis. The results were analysed using standard data processing programmes MS Excel and SPSS program package version 15.0 by descriptive analyses of each variable studied.

\section{RESULTS}

Seventy-five patients were evaluated; of these, 60 (80\%) presented with oral lesions. Females were more affected (62\%), and the institutionalized group of patients exhibited a higher incidence of oral soft-tissue lesions. In the majority of the cases, only one lesion was found (34\%), however, some patients exhibited more than one oral lesion simultaneously. The majority of the oral lesions were observed in patients who ranged in age from 60 to 74 years.

The lesions were classified according to clinical, histopathological and microbiological diagnoses and were distributed into 15 different clinical entities (Table). The more prevalent pathologies were inflammatory, reactive and associated with long-term use of prostheses or ill-adapted prostheses, since $67 \%$ of the patients with lesions were using prostheses.

Table: Prevalence of oral soft tissues lesions in the elderly

\begin{tabular}{lll}
\hline Oral lesions & $\mathbf{n}$ & $\mathbf{\%}$ \\
\hline Inflammatory lesions & & \\
Denture stomatitis & 20 & $33.3 \%$ \\
Angular cheilitis & 3 & $5 \%$ \\
Erythematous candidiasis & 6 & $10 \%$ \\
Lingua plicata & 4 & $6.7 \%$ \\
Reactive lesions & & \\
Traumatic ulcer & 2 & $3.3 \%$ \\
Premalignant and malignant lesions & & \\
Leucoplakia & 3 & $5 \%$ \\
Lichen planus & 2 & $3.3 \%$ \\
Nicotine stomatitis & 1 & $1.6 \%$ \\
Actinic cheilitis & 2 & $3.3 \%$ \\
Pigmented lesions & & \\
Nevus & 1 & $1.6 \%$ \\
Infectious lesions & & \\
Median rhomboid glossitis & 2 & $3.3 \%$ \\
Afthous ulcers & 2 & $3.3 \%$ \\
Recurrent herpes & 3 & $5 \%$ \\
Papilloma & 1 & $1.6 \%$ \\
Pseudomembranous candidiasis & 4 & $6.7 \%$ \\
Xerostomia & 4 & $6.7 \%$ \\
\hline Total & $\mathbf{6 0}$ & $\mathbf{1 0 0 \%}$ \\
\hline
\end{tabular}

\section{DISCUSSION}

Oral health is inseparable from overall health. General characteristics of the individual and the environment affect the stomatognathic system, which makes an understanding of these interactions extremely important to the diagnosis of the needs and priorities of elderly patients (10). The use of prostheses or their status could determine the number of oral lesions present in these individuals (11). In the present study, $34 \%$ of patients exhibited one lesions, $14 \%$ presented with two lesions, $3 \%$ had three lesions and $2 \%$ had four or more lesions. Similar results have been described by Jorge et al and Corbet et al $(12,13)$.

When comparing the results of the present investigation with similar epidemiological studies, the prevalence of oral lesions in $60 \%$ of 75 elderly patients is similar to previous reports by Espinoza et al (14), who reported 53\% prevalence. However, these results differed from studies from Mexico, with $95 \%$ prevalence of oral lesions reported by Mosqueda et al (15). However, it is relevant to consider that in this latter study, no distinction between pathological and non-pathological conditions was done, suggesting that the prevalence rate was higher due to the inclusions of both entities. On the other hand, Gonzalez et al (16), also in Mexico, demonstrated a prevalence of $23.2 \%$. Other series reported in Spain documented $39 \%$ of aged patients presenting with oral mucosal alterations (11).

Similar results have been shown in different studies; these variations could be due to the different methodologies used. Interestingly, in the majority of the studies, the prevalent lesions are concordant, mainly associated with adaptive changes to the mucosa due to mechanical and chemical irritation, ill-adapted prostheses, tobacco use, and to a lesser degree, other lesions related to systemic diseases and precancerous conditions.

In this study, the majority of the oral lesions were observed in patients aged 60 to 74 years, similar to the observations of Gonzalez et al (16). On the other hand, Mosqueda et al (15) had a larger age range of 56 to 86 years in their study, in agreement with the present investigation where the 75-84year age group was the second most affected with $27 \%$ of oral lesions. This could be explained due to prosthesis use in a poor condition or deficient oral hygiene, or the higher risk of developing one or more chronic diseases manifesting in the oral cavity. Of the lesions related to prosthesis use, denture stomatitis was the most common one representing 20 cases $(33.3 \%)$, in agreement with previous studies $(12,17,18)$. The second most frequent lesion in this study was erythematous candidiasis $(10 \%)$, followed by lingua plicata, xerostomia and pseudomembranous candidiasis $(6.7 \%$ each); similar results have been described by Ikebe et al (19).

The elderly population is increasing worldwide, and the importance of preparing both private and public health services for this phenomenon is becoming increasingly apparent. Planning for health services accessibility and specialized prevention for this increasing demographic should be seriously assessed, especially in developing countries. It is imperative that health professionals work as a unit, both within the dental field and otherwise. The assessment of the general health of the patient should be part of the dental treatment protocol, and should be completed well before beginning any procedure.

How treatment will affect the daily life of the patient must also be taken into consideration. A plan for appropriate treat- 
ment of elderly individuals must be cautious and allow for the development of treatment options that suit the needs of the patient. It is necessary for health professionals to develop preventative dental programmes for future generations of adults who will, one day, be part of this elderly demographic. By doing so, dental professionals will be able to better provide oral care and improve the quality of life of these patients.

\section{CONCLUSION}

Oral and perioral tissues undergo different functional and structural changes with ageing. Oral health is an important factor determining the quality of life in aged individuals. The role of the dentist and stomatologist includes the management of systemic, nutritional and pharmacological oral manifestations in order to establish an early diagnosis and subsequently, initial accurate treatment.

\section{CONFLICT OF INTEREST}

The authors declare that they have no conflict of interest.

\section{REFERENCES}

1. Koller MM. Geriatric dentistry: medical problems as well as disease-and therapy-induced oral disorders. Schweiz Rundsch Med Prax 1994; 83: 273-82.

2. Luo Y, McMillan AS, Wong MC, Zheng J, Lam CL. Orofacial pain conditions and impact on quality of life in community-dwelling elderly people people in Hong Kong. J Orofac Pain 2007; 21: 63-71.

3. Al-Aswad F. Oral findings and health status among elderly Iraqi patients (aged 65 and above). J Bagh Coll Dentistry 2008; 20: 31-3.

4. Castrejón-Pérez RC, Borges-Yáñez SA, Gutiérrez-Robledo LM, ÁvilaFunes JA. Oral health conditions and frailty in Mexican communitydwelling elderly: a cross sectional analysis. BMC Public Health 2012; 12:773-85.

5. Martin RE. Retiring some myths about ageing and oral health. J Gt Houst Dent Soc 1994; 66: 12-5.

6. Dolan TA, Gilbert GH, Duncan RP, Foerster U. Risk indicators of edentulism, partial tooth loss and prosthetic status among black and white middle-aged and older adults. Commun Dent Oral Epidemiol 2001; 29: $329-40$.
7. Espinoza I, Rojas R, Aranda W, Gamonal J. Prevalence of oral mucosal lesions in elderly people in Santiago, Chile. J Oral Pathol Med 2003; 32: $571-5$.

8. Gonsalves WC, Wrightson AS, Henry RG. Common oral conditions in older persons. Am Fam Physician 2008; 78: 845-52.

9. Kramer IR, Pindborg JJ, Bezroukov V, Infirri JS. Guide to epidemiology and diagnosis of oral mucosal diseases and conditions. World Health Organization. Community Dent Oral Epidemiol 1980; 8: 1-26.

10. Shinkai RSA, Cury AADB. [The role of dentistry in the interdisciplinary team: contributing to comprehensive health care for the elderly]. Cade Saúde Publica 2000; 16: 1099-109. In Spanish

11. Rodríguez G, Goiriera F, Mallo L. El 39\% de los ancianos españoles tienen alteraciones en mucosa bucal. Dental World; 2002. Available from: http://dentalw.com/news/26.htm

12. Jorge Júnior J, de Almeida OP, Bozzo L, Scully C, Graner E. Oral mucosal health and disease in institutionalized elderly in Brazil. Community Dent Oral Epidemiol 1991; 19: 173-5.

13. Corbet EF, Holmgren CJ, Phillipsen HP. Oral mucosal lesions in 65-74year-old Hong Kong Chinese. Community Dent Oral Epidemiol 1994; 22: 392-5.

14. Espinoza I, Rojas R, Aranda W, Gamonal J. Prevalence of oral mucosal lesions in elderly people in Santiago, Chile. J Oral Pathol Med 2003; 32: $571-5$.

15. Mosqueda A, Díaz M, Velásquez M, Irigoyen M, Caballero S, Sida E. Prevalencia de alteraciones de la mucosa bucal en el adulto mayor. Estudio en dos grupos del sur de la ciudad de México. Temas Sel Investig Clin 1998; IV: 39-50.

16. González López B, González Huidobro L, Bobadilla Díaz A. Prevalencia de patología bucal y de estructuras relacionadas en el paciente geriátrico de la región I del estado de México. Rev ADM 1995; 52: 129-37.

17. Munevar Torres AM, Rojas García J, Rojas García JK, Marín Zuluaga DJ. Perfil epidemiológico bucal de los pacientes de 55 años y más que asisten a las clínicas del geronte a la facultad de odontología de la UN durante el primer semestre del año 2000 y cual es la percepción que tienen estos pacientes sobre su propio estado de salud bucal. Rev Fed Odontol Colomb 2002; 61: 4-22.

18. Van der Maarel-Wierink CD, Vanobbergen JNO, Bronkhorst EM, Schols JMGA, de Baat C. Oral health care and aspiration pneumonia in frail older people: a systematic literature review. Gerodontology 2013; 30: $3-9$.

19. Ikebe K, Morii K, Matsuda K, Hata K, Nokubi T. Association of candidal activity with denture use and salivary flow in symptom-free adults over 60 years. J Oral Rehabil 2006; 33: 36-42. 